\title{
COMPARISON OF THIN LAYER CHROMATOGRAPHY (TLC) AND GAS CHROMATOGRAPH DETERMINATION OF PROPOXUR RESIDUES IN A COCOA ECOSYSTEM
}

\author{
Philip O. Yeboah"; S Lowor** and C.K. Akpabli ${ }^{* * *}$ \\ *Department of Chemistry, National Nuclear Research Institute, P. O. BOX LG 80, Legon Ghana \\ ${ }^{* *}$ Cocoa Research Institute of Ghana, \\ ${ }^{* * *}$ Department of Chemistry, University of Ghana, Legon
}

\begin{abstract}
The fate of propoxur in a cocoa ecosystem has been studied using TLC and GC. Residues of propoxur as determined by both TLC and GC were not significantly different. TLC analysis of propoxur residues in soil, cocoa leaves and pods may not need any rigorous clean up since residues measured from cleaned and uncleaned extracts were not significantly different. The residue levels of propoxur in the soil were found to decrease rapidly and, by the $21^{\text {st }}$ day, none was detected in the topsoil $(0-15 \mathrm{~cm})$. Evidence of leaching of propoxur residues in the soil environment has also been demonstrated. The amount left in the top soil after the first seven days were $27 \%, 23 \%$ and $24 \%$ as determined by the TLC only, TLC with clean-up and GLC respectively. About $38 \%$ of pesticides detected on the cocoa pod on the day of treatment remained as residues on the pod seven days after treatment. The residue detected on the leaves on the day of treatment was higher than that for the soil. This decreased rapidly to $1.7 \%$ in 21 days compared to $16 \%$ for the soil and $23 \%$ for the pod. No propoxur residue was detected 21 days after spraying.
\end{abstract}

\section{INTRODUCTION}

Propoxur is one of two pesticides registered in Ghana and recommended for the control of capsids in cocoa. The application is carried out four times a year on prophylactic basis (i.e. calendar spray) in August, September, October and December [1]. Propoxur is a toxic compound, with moderate to low persistence with reported field half-lives of 14 to 50 days, in the soil environment [2]. Propoxur can also enter the roots of a plant and travel to the leaves, where it can then poison insects that feed on the leaves, and can have residual activity of up to 1 month when applied to plant surfaces [3]. Additionally, cocoa is usually cultivated in a multicropping system in Ghana. It is for these reasons that the fate of propoxur in a cocoa ecosystem must be known.

The traditional method for determining pesticide residues including propoxur is by gas chromatography or High Performance Liquid Chromatography [4]. Thin layer chromatography (TLC) is, however, again, gaining popularity as an important analytical tool for analysis of pesticides [5].
This is due to the fact that TLC offers the opportunity to undertake analysis where a combination of factors including, inaccessibility to instrumental service facilities, spare parts and continuous electricity supply, makes analysis almost impossible. The objectives of this study are therefore:

- to determine the fate of propoxur residues in cocoa ecosystem using GC and TLC; and

- to compare the efficiency of recovery of the two methods of determination.

\section{MATERIALS AND METHODS}

\section{Chemicals and Reagents}

Ethyl acetate, dichloromethane and benzene were analytical grade and obtained from Fluka Chemie AG, Industriestrasse 25, CH-9470 Buchs, Switzerland.

Pesticide standards were purchased from DR Ehrenstorfer Gmbh, Ausberg, Fed Rep. of Germany; and and had purity ranging from $94.0 \%$ to $99.5 \%$. 
All other chemicals were obtained from Merck KgaA, D64271 Darmstadt, Frankfurterstrasse 250, Germany.

Preparation of standard solutions: $1.0 \mathrm{mg} / \mathrm{ml}$ primary standard stock solution of propoxur used in this study was prepared by dissolving approximately $0.05 \mathrm{~g}$ pure pesticide (corrected for standard purity, e.g. for $\%$ purity of 94 , $0.05 \times 100 / 94 \mathrm{~g}$ was weighed) in $50 \mathrm{ml}$ acetone.

Tris (hydroxy-ethyl) aminoethane:- $3.04 \mathrm{~g}$ was dissolved in $500 \mathrm{~mL}$ double distilled water to give $0.05 \mathrm{M}$ trisbuffer.

Pig blood serum.:- Pig blood was collected from the University of Ghana Research farm at Nungua, and congealed at $2-3^{\circ} \mathrm{C}$ for one hour, and the separated blood serum was centrifuged for 10 minutes at $4000 \mathrm{rpm}$. Serum was collected in $10 \mathrm{ml}$ portions and kept frozen until use. Cholinesterase activity was adjusted to $140 \mathrm{U} / \mathrm{L}$ by dilution with tris buffer (Tris (hydroxy-ethyl) aminoethane solution) before use.

2,6 -dichloro-indophenol $\mathrm{Na}$-salt:- $50 \mathrm{mg}$ of the salt was dissolved in $50 \mathrm{mg}$ distilled water to give $1 \mathrm{mg} / \mathrm{mL}$ solution.

Acetylthiocholine iodide.: was prepared by dissolving 45 $\mathrm{mg}$ of the compound in distilled water (i.e. $1.5 \mathrm{mg} / \mathrm{ml}$ aqueous solution).

\section{Apparatus}

TLC plates $(20 \times 20 \mathrm{~cm})$ Silica gel $60 \mathrm{~F} 254(5721,5715)$ and TLC plates $(20 \times 20 \mathrm{~cm})$ :- Aluminum oxide G (5713) were purchased from Merck (E) Gmbh, Germany.

TLC basic set including application guide, atomizer and developing tank were obtained from Camag ChemieErzeugnisse und Adsorptionstechnik AG, Sonnenmattstrasse 11, CH-4132, Muttenz, Switzerland.

Micro syringes $(10 \mu L)$ with needle (Hamilton) were obtained from Supelco Inc., Supelco Park, Bellefork, Pa U.S.A.

\section{Pesticide Treatment}

The experiment was conducted on a 6-hectare cocoa plantation plot situated at the Cocoa Research Institute, Tafo in the Eastern Region of Ghana.

Four pots, each measuring $15 \mathrm{~m} \times 15 \mathrm{~m}$ were marked out. The plot that had been earmarked for pesticide treatment was sprayed with a water emulsion of commercial propoxur at a dose of $50 \mathrm{~g} / \mathrm{litre}$ of water . The spraying was done from two sides of a tree trunk into the canopy, as has been the normal practice (T2 method) to achieve adequate coverage. In line with the recommended practice application of pesticide was repeated three weeks after the first application. The pod, leaves and soil samples were taken before, on the day of treatment and subsequently, at weekly intervals for two months for analysis.

Soil samples were taken at depths of 0 to $15 \mathrm{~cm}$ and 15 $30 \mathrm{~cm}$ respectively for analysis. Eight cores of soils were sampled at random from each sub-plot using a soil auger $(2.5 \mathrm{~cm}$ in diameter and $20 \mathrm{~cm}$ deep $)$. The cores were weighed before and after removal of stones and ground to pass through a $2.5 \mathrm{~cm}$ sieve. The ground cores were mixed thoroughly to provide one bulk. Sub-samples in triplicate were taken for residue analysis at stated intervals. Propoxur residues was determined by TLC and GLC.

\section{Extraction and Clean Up}

\section{Leaves and pod}

Leaf tissue $(60 \mathrm{~g})$ or the peeled skin of the pods $(60 \mathrm{~g})$ were treated as follows: The sample was homogenised with $60 \mathrm{ml}$ ethylacetate in the presence of $50 \mathrm{~g} \mathrm{NaHCO}_{3}$ and $50 \mathrm{~g}$ anhydrous sodium sulphate. The extract was kept in a fume hood for 30 minutes to allow separation of the solvent from the solid material. The decanted solvent was filtered through a small cotton wool plug into a measuring cylinder to obtain a $30 \mathrm{ml}$ filtrate $(1 \mathrm{ml}=1 \mathrm{~g}$ sample). The filtrate was evaporated to $3 \mathrm{ml}$ and transferred into a calibrated conical test tube. The evaporation was continued to near dryness with a gentle stream of nitrogen. Three milliliters of ethyl acetate was added and evaporation repeated two more times. The final volume was adjusted to $2 \mathrm{ml}$ with ethylacetate for clean up using GPC.

\section{Clean Up on S-X3 Gel Column}

A 5.6G SX-3 bead, previously soaked for 6 hours in cyclohexane/ethylacetate $(1+1)$ was packed into a $10 \mathrm{~mm}$ i.d. $\times 20 \mathrm{~cm} \times 1.2 \mathrm{~mm}$ thick Pyrex gel column under Nitrogen pressure. Cyclohexane/ ethylacetate $(1+1)$ solvent mixture was pumped under pressure from a solvent reservoir by means of nitrogen gas through the column. Flow rate was adjusted to $1.5 \mathrm{ml} / \mathrm{min}$ following calibration with standard propoxur solution. $200 \mu \mathrm{l}$ of the extract were injected into the column and fractions 
collected were concentrated to $100 \mu \mathrm{l}$ under nitrogen for direct spotting of $10 \mu \mathrm{l}$ of resultant extract on TLC plates. The extract was also made up to $2 \mathrm{ml}$, and $5 \mu \mathrm{l}$ used for gas chromatographic determination.

\section{Soil:}

Triplicate soil samples (50 g), which had been sieved through $2 \mathrm{~mm}$ mesh, were soxhlet extracted for 5 hours with $250 \mathrm{ml}$ methanol. A $50 \mathrm{ml}$ aliquot of methanol extract was evaporated to dryness in a rotary evaporator and the residue taken up in $1 \mathrm{ml}$ methanol: water mixture $(1: 2.5)$. The diluted extract was passed through a reconditioned C-18 solid phase extraction (SPE) column at a flow rate of $2 \mathrm{ml} / \mathrm{min}$. The column was vacuum dried for 15 minutes, following which the pesticide was eluted with $2 \mathrm{ml}$ Toluene. $5 \mu \mathrm{l}$ was injected onto the GC, whilst $10 \mu \mathrm{l}$ aliquot was analysed by TLC using enzyme inhibition method of detection.

\section{Recovery Experiments}

Leaves and pods: $60 \mathrm{~g}$ each of cocoa pods and leaves were spiked with various amounts of propoxur standard as described in Table 4. Samples were homogenised, extracted and cleaned up as described above, and subsequently analysed by GC and TLC as described below. Fortification of leaves and pods with $1.05 \mathrm{~g}$ propoxur gave recoveries of $75 \%$ and $80 \%$ for gas chromatographic analysis.

\section{GAS LIQUID CHROMATOGRAPHIC ANALYSIS}

A Varian star 3400CX GC equipped with a Thermionic specific detector (TSD) and a $15 \mathrm{~m}(0.53 \mu \mathrm{m}$ i.d. $\times 1.5$ $\mu \mathrm{m}$ film) $\mathrm{J} \& \mathrm{~W} \mathrm{DB}=5$ capillary column. The nitrogen gas flow rate was $9 \mathrm{ml} / \mathrm{min}$ with the following operating conditions: injector temperature: $230^{\circ} \mathrm{C}$; Detector Temperature: $300{ }^{\circ} \mathrm{C}$ and column $60 \mathrm{~min}$ for $20 \mathrm{~min}$. and $200^{\circ} \mathrm{C}$ for 12 minutes.

\section{THIN LAYER CHROMATOGRAPHICANALYSIS}

\section{Spotting of pesticides on TLC plates}

Freshly activated plates were used. Spotting was done manually. $10 \mu \mathrm{l}$ of the extracts (cleaned or uncleaned) was applied to the sorbent layer with a syringe, with a $90^{\circ}$ cut needle tip. Standards were applied in spots of the same size; this was achieved by spotting the same volume, using the same solvent. The spots were applied with a spotting guide, allowed to dry before applying again until the whole volume has been applied. Care was taken to include a marker compound on each plate.

\section{Development of plates}

Between 10 to $20 \mu \mathrm{L}$ of pesticide standard was spotted on chromatographic plate. The entire plate was placed in $1 \mathrm{~cm}$ eluting solvent in saturated developing tank. The plate was eluted until solvent front moved $10 \pm 0.5 \mathrm{~cm}$ from the origin.

\section{Detection of Pesticides}

The enzyme inhibition method described by Ambrus et al. 2003, was used to detect propoxur residues.

Air-dried plate was treated with bromine and enzyme solution. After incubation at $37^{\circ} \mathrm{C}$ for 30 minutes, excess water was removed with air steam. Substrate solution was later sprayed on plate, and the latter was subsequently incubated for another 15 mins. The reagent solution was then sprayed on the plate. Propoxur appeared as Blue spots on white background.

\section{Quantitative analysis by TLC}

For Quantitative Analysis by TLC, a number of standards were spotted on the same plate with the samples. After development and visualisation, the sample spots were visually compared with the standard spots. The concentration of the sample is then taken as that of the standard spot for which the intensity and size are about the same.

\section{RESULTS AND DISCUSSIONS}

The averages of the residue levels of propoxur in soils from treated plots is presented in Table 1 .

The propoxur residues in the soil decreased rapidly from an initial level of about $0.7 \mu \mathrm{g} / \mathrm{g}$, and, by the $21^{\text {st }} \mathrm{day}$, none was detected in the topsoil $(0-15 \mathrm{~cm})$. The amount left in the top soil after the first seven days were $0.21,0.16$, and $0.18 \mu \mathrm{g} / \mathrm{g}$ representing $27 \%, 23 \%$ and $24 \%$ as determined by the TLC without clean-up, TLC with cleanup and GLC respectively. The results of the analysis from the various methods of analysis gave very good correlation. No propoxur residues were however detected in the deep soil $(15-30 \mathrm{~cm})$ on the day of treatment. Residue levels in the deep soil started accumulating and reached a maximum of $0.98 \mu \mathrm{g} / \mathrm{g}$ within 14 days, thereafter it decreased and none was detected 21 days after the first treatment. The total amount of pesticide residues measured within the top 0-30 $\mathrm{cm}$ of soil on the $7^{\text {th }}$ and $14^{\text {th }}$ day of application was about double the amount detected in the top $0-15 \mathrm{~cm}$ of soil on the $1^{\text {st }}$ day of application using TLC analysis. This might be due 
Comparison of Thin Layer Chromatography (TLC) and Gas Chromatograph Determination of Propoxur Residues in a Cocoa Ecosystem

Table 1: Residue levels of propoxur in soil as determined by GLC and TLC

\begin{tabular}{|c|c|c|c|c|}
\hline \multicolumn{5}{|c|}{ MEANRESIDUELEVEL $(\mu \mathrm{g} / \mathrm{g})$} \\
\hline $\begin{array}{l}\text { DAYOF } \\
\text { SAMPUING }\end{array}$ & $\begin{array}{l}\text { DEPTHSAMPLED } \\
\mathrm{cm}\end{array}$ & TLC** & $\mathrm{TLC}^{* * * *}$ & GLC \\
\hline Pretreatment & $0-15$ & N.D & N.D & N.D \\
\hline & $15-30$ & N.D & N.D & N.D \\
\hline Day of & $0-15$ & $0.79 \pm 0.21$ & $0.70 \pm 0.09$ & $0.76 \pm 0.12$ \\
\hline Treatment & $15-30$ & N.D & N.D & N.D \\
\hline 7 days after & $0-15$ & $0.21 \pm 0.09$ & $0.16 \pm 0.05$ & $0.18 \pm 0.04$ \\
\hline treatment & $15-30$ & $0.81 \pm 0.04$ & $0.58 \pm 0.18$ & $0.64 \pm 0.01$ \\
\hline 14 days after & $0-15$ & $0.53 \pm 0.11$ & $0.79 \pm 0.16$ & $0.46 \pm 0.03$ \\
\hline treatment & $15-30$ & $0.98 \pm 0.05$ & $0.90 \pm 0.08$ & $0.10 \pm 0.05$ \\
\hline 21days after & $0-15$ & N.D & N.D & N.D \\
\hline treatment & $15-30$ & $0.13 \pm 0.09$ & $0.11 \pm 0.07$ & $0.12 \pm 0.06$ \\
\hline 7 days after & $0-15$ & $0.69 \pm 0.10$ & $0.51 \pm 0.09$ & $0.68 \pm 0.03$ \\
\hline $2^{\text {nd }}$ treatment & $15-30$ & N.D & N.D & N.D \\
\hline 14 days after & $0-15$ & $0.46 \pm 0.11$ & $0.28 \pm 0.08$ & $0.41 \pm 0.04$ \\
\hline $2^{\text {nd }}$ treatment & $15-30$ & N.D & N.D & N.D \\
\hline 21days after & $0-15$ & N.D & N.D & N.D \\
\hline $2^{\text {nd }}$ treatment & $15-30$ & N.D & N.D & N.D \\
\hline
\end{tabular}

Results in Triplicates

TLC** - Results without clean up.

TLC*** - Results with clean up.

N.D. $\quad$ - Not detected.

to the fact that the heavy rainfall immediately after the first application washed down pesticides from the canopy of leaves and pods onto the soil.

The initial accumulation could be attributed to leaching from the topsoil considering the heavy rainfall within the period of the survey. The rapid dissipation of propoxur from the soil between the $14^{\text {th }}$ and $21^{\text {st }}$ day after application however could be attributed to the high temperatures during the experimental period $\left(30 \pm 3^{0}\right.$ C). Increasing temperature is known to increase the rate of loss of pesticides from soils as well as bacterial degradation [6].

About 38\% ( 0.26 and $0.33 \mu \mathrm{g} / \mathrm{g}$ depending on method of analysis) of propoxur residues detected on the pod on the day of treatment remained seven days after treatment (Table 2). The residue levels of propoxur measured on the pod on the day of treatment was higher than that for the soil. This is expected because the application of the
Table 2: Residue levels of propoxur on cocoa pod as determined by GLCand TLC.

\begin{tabular}{|c|c|c|}
\hline \multicolumn{3}{|c|}{ MEAN RESIDUE LEVELS $(\mu \mathrm{g} / \mathrm{g})$} \\
\hline DAYOF & & \\
\hline SAMPLING & $\mathrm{TLC}^{* * *}$ & GLC \\
\hline Pretreatment & N.D & N.D \\
\hline $\begin{array}{l}\text { Day of } \\
\text { Treatment }\end{array}$ & $0.92 \pm 0.17$ & $0.79 \pm 0.21$ \\
\hline $\begin{array}{l}7 \text { days after } \\
\text { treatment }\end{array}$ & $0.26 \pm 0.08$ & $0.21 \pm 0.09$ \\
\hline $\begin{array}{l}14 \text { days after } \\
\text { treatment }\end{array}$ & $0.19 \pm 0.06$ & $0.53 \pm 0.11$ \\
\hline $\begin{array}{l}\text { 21days after } \\
\text { treatment }\end{array}$ & $0.09 \pm 0.04$ & N.D \\
\hline $\begin{array}{l}7 \text { days after } \\
2^{\text {nd }} \text { treatment }\end{array}$ & $0.25 \pm 0.06$ & $0.69 \pm 0.10$ \\
\hline $\begin{array}{l}14 \text { days after } \\
2^{\text {nd }} \text { treatment }\end{array}$ & $0.07 \pm 0.03$ & $0.46 \pm 0.11$ \\
\hline $\begin{array}{l}21 \text { days after } \\
2^{\text {nd }} \text { treatment }\end{array}$ & N.D & N.D \\
\hline
\end{tabular}

$\begin{array}{ll}\text { TLC*** } & \text { - Results with clean up. } \\ \text { N.D. } & \text { - Not detected. }\end{array}$

insecticide was to the plant with the amount in the soil giving an indication of the inefficiency or efficiency of the spraying.

The average of the results of leaf analysis obtained from the four subplots for the cocoa trees are shown on table 3. The initial residue found on the leaf was far higher than for the pod and the soil. Forty-five percent of the initial propoxur residue detected on the day of treatment remained 7 days after treatment. This decreased rapidly to $1.7 \%$ in 21 days compared to $16 \%$ for the soil and $23 \%$ for the pod. The dissipation was therefore higher in the leaves. This can be attributed to the fact that the leaves are more exposed to the direct sunlight, wind and rainfall which causes dissipation and washing of surface easily compared to the soil which was virtually shaded from the sun by the canopy of the trees. The pods, also hiding in the canopy are somehow shielded. The TLC methodology could however not detect any residue on the $21^{\text {st }}$ day after the first treatment for the leaf because it was below its detection limit. 
Table 3: Residue levels of propoxur in cocoa leaves as determined by GLCand TLC

\begin{tabular}{|c|c|c|}
\hline \multicolumn{3}{|c|}{ MEAN RESIDUE LEVELS $(\mu \mathrm{g} / \mathrm{g})$} \\
\hline DAYOF & & \\
\hline SAMPLING & TLC **** & GLC \\
\hline Pretreatment & N.D & N.D \\
\hline $\begin{array}{l}\text { Day of } \\
\text { Treatment }\end{array}$ & $1.67 \pm 0.42$ & $1.75 \pm 0.12$ \\
\hline $\begin{array}{l}7 \text { days after } \\
\text { treatment }\end{array}$ & $0.65 \pm 0.33$ & $0.76 \pm 0.20$ \\
\hline $\begin{array}{l}14 \text { days after } \\
\text { treatment }\end{array}$ & $0.07 \pm 0.01$ & $0.05 \pm 0.01$ \\
\hline $\begin{array}{l}\text { 21days after } \\
\text { treatment }\end{array}$ & N.D & $0.03 \pm 0.01$ \\
\hline $\begin{array}{l}7 \text { days after } \\
2^{\text {nd }} \text { treatment }\end{array}$ & $0.93 \pm 0.06$ & $1.02 \pm 0.11$ \\
\hline $\begin{array}{l}14 \text { days after } \\
2^{\text {nd }} \text { treatment }\end{array}$ & $0.39 \pm 0.10$ & $0.46 \pm 0.15$ \\
\hline $\begin{array}{l}21 \text { days after } \\
2^{\text {nd }} \text { treatment }\end{array}$ & $0.05 \pm 0.02$ & $0.08 \pm 0.01$ \\
\hline $\begin{array}{l}28 \text { days after } \\
2^{\text {nd }} \text { treatment }\end{array}$ & $0.05 \pm 0.02$ & $0.01 \pm 0.01$ \\
\hline $\begin{array}{l}\text { TLC**** } \\
\text { N.D. }\end{array}$ & $\begin{array}{l}\text { ults with cle } \\
\text { detected. }\end{array}$ & \\
\hline
\end{tabular}

Table 4:Recovery of Propoxur by TLC/Enzyme inhibition with acetylcholine iodide substrate method

Matrix: cocoa leaves

MDQ5ng

\begin{tabular}{|l|l|l|l|l|}
\hline $\begin{array}{l}\text { Fortification levels } \\
(\mathrm{mg} / \mathrm{kg})\end{array}$ & $\mathrm{n}$ & $\begin{array}{l}\text { Recovery } \\
(\mathrm{mg} / \mathrm{kg})\end{array}$ & $\begin{array}{l}\text { Recovery } \\
\%\end{array}$ & S.D \\
\hline $0.25(1 \mathrm{MDQ})$ & 3 & $\mathrm{ND}$ & $\mathrm{ND}$ & - \\
\hline $0.50(2 \times \mathrm{MDQ})$ & 3 & 0.36 & 66 & 10 \\
\hline $1.0(4 \times \mathrm{MDQ})$ & 3 & 0.7 & 70 & 4 \\
\hline & & & & \\
\hline $0.25+\mathrm{GPC}$ & 3 & $\mathrm{ND}$ & $\mathrm{ND}$ & - \\
\hline $0.50+\mathrm{GPC}$ & 3 & 0.26 & 52 & 20 \\
\hline $1.0+\mathrm{GPC}$ & 3 & 0.64 & 64 & 7 \\
\hline
\end{tabular}

\section{CONCLUSION}

Residues of propoxur as determined by both TLC and GC were not significantly different. TLC analysis of propoxur residues in soil, cocoa leaves and pods may not need any rigorous clean up since residues measured from cleaned and uncleaned extracts were not significantly different. The results presented shows the potential of using TLC to cut down cost.

No propoxur residues could be detected in the cocoa ecosystem 21 days after spraying. The rate of dissipation was faster in the leaves than in the soils or the pods

\section{ACKNOWLEDGEMENT}

This work was supported in part by the International Atomic Energy Agency under Research Contract No. 9370. The authors also acknowledge the contribution of Messrs. B. Q. Modzinuh and S. Afful of the Chemistry Dept. of the National Nuclear Research Institute for their assistance in various ways.

\section{REFERENCES}

[1] Gerkens A., Suglo J. V. and Braun M. 2000 in Crop Protection Policy in Ghana. An Economic Analysis of Current Practicies and Factors Influencing Pesticide Use (DRAFT) 2000

[2] Wauchope, R. D.; Buttler, T. M.; Hornsby, A. G.; Augustijn-Beckers, P. W. M. and Burt, J. P. SCS/ ARS/CES pesticides properties database for environmental decision making. Rev. Environ. Contam. Toxicol. 123:3-14. 1992

[3] Akerblom, M. and Cox, J. R.; In World Directory of Pesticide Control Organisations, $3^{\text {rd }}$ Edition, Royal Chem. Soc., England, Edited by Ekstrom G., 1-17.1996

[5] U.S. National Library of Medicine , Hazardous Substances Databank. Bethesda, MD, 3-9. 1995

[6] Ambrus, A.: "Development of Cost Effective Screening methods for pesticide Residues in vegetables" International Atomic Energy Agency (IAEA). Final Report. 8908/R 1998

[7] Edwards C. A.; Residue Reviews, , 13, 83. 1996 